\title{
PENGARUH KEMAMPUAN DALAM MEMBACA AL-QURAN TERHADAP HASIL BELAJAR MATA PELAJARAN AL-QURAN HADITS PESERTA DIDIK
}

\section{EFFECT OF ABILITY IN READING THE AL-QURAN ON THE RESULT OF LEARNING SUBJECTS AL-QURAN HADITH LEARNERS}

\author{
R Ramadhani1a \\ 1 Program Studi Manajemen Pendidikan Islam, Fakultas Keguruan dan Ilmu Pendidikan, \\ Universitas Djuanda Bogor, Jl. Tol Ciawi No. 1 Kotak Pos 35 Ciawi Bogor 16720 \\ a Korespondensi: Risty Ramadhani, Email: risthi21@gmail.com \\ (Diterima: 08-03-2018; Ditelaah: 08-03-2018; Disetujui: 16-04-2018)
}

\begin{abstract}
This study aims to examine the effect of the ability to read al-quran on the results of learning subjects of al-quran hadith learners. The approach used is an associative quantitative approach in the form of cause and effect. The sample used were 55 students from the population of 122 students in MA Miftahul Huda. The data were obtained by using techniques such as practice test, observation, interview and documentation. The final result of this study illustrates the significance of the regression equation with the result of $\mathrm{F}_{\text {count }}$ 77.927 and $F_{\text {table }}$ with dfreg $=1$ dfres $=54$ is 4.03 at $5 \%$ level. Thus $F_{\text {count }}>F_{\text {table }}(29.577>$ 4.03) so that $\mathrm{HO}$ is rejected, it means there is a significant influence between the ability of reading the Qur'an to the learning outcomes. The coefficient of determination is $0.7712=$ 0.595 thus the learning result of Alquran hadith is $59.5 \%$ influenced by the ability to read Alquran, while $40.5 \%$ of Al Quran Hadith study results are influenced by other factors.
\end{abstract}

Keywords: ability to read the quran, the hadith Quranic learning outcomes.

\begin{abstract}
ABSTRAK
Penelitian ini bertujuan untuk menguji pengaruh kemampuan dalam membaca al-quran terhadap hasil belajar mata pelajaran al-quran hadits peserta didik. Pendekatan yang digunakan adalah pendekatan kuantitatif asosiatif berupa sebab akibat. Sampel yang digunakan yaitu sebanyak 55 peserta didik dari populasi 122 peserta didik di MA Miftahul Huda T/A 2016/2017. Data diperoleh menggunakan teknik yaitu tes praktik, observasi, wawancara dan dokumentasi. Hasil akhir penelitian ini menggambarkan signifikansi persamaan regresi dengan hasil nilai $F_{\text {hitung }} 77.927$ dan $F_{\text {tabel }}$ dengan $\mathrm{df}_{\text {reg }}=1 \mathrm{df}_{\text {res }}=54$ adalah 4,03 pada taraf 5\%. Dengan demikian $F_{\text {hitung }}>\mathrm{F}_{\text {tabel }}(29.577>4,03)$ sehingga $\mathrm{H}_{0}$ ditolak, artinya terdapat pengaruh yang signifikan antara kemampuan membaca Alquran terhadap hasil belajar. Koefisien determinasi yaitu $0,771^{2}=0.595$ dengan demikian hasil belajar Alquran hadits sebesar 59,5\% dipengaruhi oleh kemampuan membaca Alquran, sedangkan 40.5\% hasil belajar Al-Quran Hadits dipengaruhi oleh faktor lain.
\end{abstract}

Kata kunci: Kemampuan membaca Al-Quran, hasil belajar Al-Quran Hadits.

Ramadhani, R. (2018). Pengaruh Kemampuan dalam Membaca Al-Quran Terhadap Hasil Belajar Mata Pelajaran Al-Quran Hadits Peserta didik. Tadbir Muwahhid, 2(1), 1-10. 


\section{PENDAHULUAN}

Di zaman yang serba teknologi, mengajarkan anak untuk mencintai AlQuran bukanlah persoalan yang sederhana. Banyaknya hiburan yang tersedia ditelevisi maupun gadget anak di zaman lebih di minati dari pada minat anak untuk mempelajari Al-Quran. Hadirnya internet menyebabkan pergeseran budaya, dari budaya media tradisional menjadi budaya media yang digital. Mengajarkan Al-Quran merupakan hak anak dan kewajiban utama yang harus ditunaikan orang tua yang sesegera mungkin. Mengenalkan Al-Quran kepada anak haruslah dilakukan sejak anak berada diusia dini oleh orang tua, tugas ini memerlukan keseriusan yang tinggi dan kepedulian dari setiap orang tua dan pendidik. Tujuannya agar anak berkembang sesuai dengan fitrahnya serta mengajarkan Al-Quran adalah salah satu pokok dalam ajaran agama Islam.

Dalam mendidik anak, pendidik harus memperhatikan cara yang tepat sesuai dengan kondisi sang anak. Orang tua adalah guru pertama dan utama karena ibu adalah madrasah pertama bagi anak. Apabila menginginkan anak menjadi pencinta AlQuran, hal utama yang harus dilakukan yaitu orang tua terlebih dulu juga mengenal Al-Quran.

Al-Quran yaitu kitab suci umat agama Islam yang diturunkan Allah SWT kepada Rasulullah SAW melalui malaikat jibril. Untuk menjadi petunjuk \& pedoman hidup di dunia menuju akhirat. Al-Quran adalah kesempurnaan dan mukjizat terbesar yang diturunkan Allah SWT kepada Rasul-nya yang mana Al-Quran perlu dibaca, dipelajari, dan diperoleh maknanya untuk implementasikan dikehidupan dan mempelajarinya yaitu merupakan ibadah. Membaca Al-Quran tidak hanya cukup bisa dapat melafalkan huruf-huruf hijaiyahnya saja, tetap harus memperhatikan ilmu tajwid dan kepashihan dalam melafalkan huruf-huruf hijaiyah seperti halnya ayat berikut yang artinya:

"Bacalah kitabmu, cukuplah dirimu sendiri pada waktu ini sebagai penghitung atas terhadapmu" (Qs Al-Isra 14) (Departemen Agama R.I, 1971).

Al-Quran dan hadits adalah dua sumber umat agama Islam sebagai tuntunan menjalankan ibadahnya. Oleh karena itu, pemahaman keduanya merupakan keharusan bagi umat islam. Sebagai umat agama Islam yang menjalankan perintah Tuhannya dengan baik, membaca Al-Quran harus bacaan yang pashih dan tidak terbata-bata sewajibnya menjadi kebiasaan rutin sekaligus kegiatan sehari-hari.

Pendidikan Al-Quran hadits ialah mata pelajaran yang harus di ampuh oleh murid MA Miftahul Huda. Peranan Al-Quran hadits ini memiliki kontribusi yang besar dalam memberikan pelajaran pengalaman pada para peserta didik untuk mengaplikasikan nilai-nilai keyakinan keagamaan (tauhid) dan akhlakul karimah dalam kehidupan sehari-hari. Kebiasaan ini dijadikan metode pendidikan yang berisikan pengalamanpengalaman atau kebiasaan-kebiasaan tertentu ( Tafsir, 2004).

Membaca adalah suatu proses yang dilakukan serta dipergunakan oleh pembaca untuk memperoleh pesan, yang hendak disampaikan oleh penulis melalui media kata-kata bahasa tulis (Departemen Pendidikan Nasional, 2008). Membaca merupakan kemampuan yang harus dimiliki oleh setiap peserta didik, karena melalui membaca peserta didik dapat belajar berbagai bidang studi (Susanto, 2013). Kemampuan membaca tidak hanya akan meningkatkan keterampilan kerja atau penguasaan berbagai bidang akademik 
seseorang, namun juga agar dapat berpartisipasi dalam kehidupan sosial budaya, politik, dan memenuhi kebutuhan emosional.

Al-Quran adalah kitab suci umat islam yang diwahyukan Allah SWT kepada nabi Muhammad SAW melalui malaikat jibril diturunkan secara berangsur-angsur sebagai pedoman dan petunjuk hidup. Alquran di pandang sebagai mukjizat Nabi Muhammad SAW yang palig besar dan abadi, serta pedoman hidup manusia untuk mencapai kebahagiaan dunia akhirat, maka sudah seharusnya cara membaca Al-Quran diatur sedemikian rupa, sehingga pembaca mendapat berkah-Nya yang bersifat hissi maupun yang bersifat maknawi.

Membaca Al-Quran secara kelancaran saat membacanya saja tidak cukup, tetapi juga memperhatikan kaidah-kaidah tajwid serta ketepatan dalam melafalkan hurufhuruf hijaiyah. Untuk itu pihak sekolah menetapkan peraturan siswa diminta membaca Al-Quran terlebih dahulu meskipun 10 ayat maka dalam membaca AlQuran akan lebih mudah. Selain itu agar siswa mahir dalam ilmu Al-Quran di sekolah melalui kegiatan tadarus ini dapat meningkatkan hasil belajar mata pelajaran Al-Quran Hadits. Namun demikian masih ada siswa yang tingkat kemampuan membaca Al-Qurannya rendah. Sebagaimana hasil dari observasi awal peneliti di MA Miftahul Huda, menunjukkan bahwa sebanyak $20 \%$ peserta didik mempunyai kemampuan membaca AlQuran rendah (Pedoman Hasil wawancara bersama Bapak Agus Ma'mun selaku guru pengampu mata pelajaran Alquran Hadits MA Miftahul Huda).

Berangkat dari pemaparan dan dasar pandangan ini, maka penelitii tertarik melakukan penelitian dengan judul "Pengaruh Kemampuan Dalam Membaca Al-
Quran terhadap Hasil Belajar Al-Quran Hadits".

\section{MATERI DAN METODE}

\section{Jenis Penelitian}

Penelitian ini menggunakan pendekatan penelitian kuantitatif. Penelitian kuantitatif yaitu penelitian yang digunakan untuk menjawab permasalahan yang diteliti melalui teknik pengukuran yang tepat terhadap variabel-variabel tertentu, sehingga menghasilkan simpulan-simpulan yang dapat digeneralisasikan. Pendekatan kuantitatif memungkinkan dilakukannya pencatatan hasil penelitian dalam bentuk angka dan analisis menggunakan statistik. Selain itu pendekatan penelitian kuantitatif juga digunakan untuk meneliti permasalahan yang sudah jelas, data dapat diamati dan dapat diukur, peneliti bermaksud untuk menguji hipotesis dan generalisasi (Arifin, 2012).

Penelitian ini bersifat korelasi kausal, yang berfungsi mengetahui pengaruh variable $\mathrm{X}$ (Kemampuan Membaca AlQuran) terhadap variable Y (Hasil Belajar Al-Quran Hadits). Sedangkan alat analisis yang digunakan dalam penelitian ini yaitu menggunakan analisis regresi. Metode regresi digunakan untuk mengetahui bagaimana antar variabel saling berhubungan.

\section{Waktu Dan Tempat Penelitian}

Penelitian ini dilaksanakan di Madrasah Aliyah Miftahul Huda. Alamat Madrasah :Jl. Raya Puncak Megamendung No. 64 Cipayung girang Megamendung Bogor 16770. Penelitian ini dilaksanakan selama kurang lebih 5 bulan, dimulai dari bulan oktober 2016-februari 2017. Dalam kurun waktu tersebut peneliti membagi penelitian 
ini ke dalam beberapa tahapan. Yaitu tahap persiapan, tahap pengumpulan data, tahap pengolahan dan analisis data, serta tahap penulisan laporan.

\section{Populasi Dan Sampel}

Populasi adalah jumlah keseluruhan dari objek maupun subjek yang memiliki karakteristik tertentu yang telah ditetapkan oleh peneliti untuk diteliti dan selanjutnya disimpulkan (Sujarweni, 2014). Adapun populasi yang menjadi objek penelitian ini adalah seluruh peserta didik MA Miftahul Huda Cipayung Bogor tahun ajaran 2016/2017 yang berjumlah 122 siswa yang terbagi dari tiga kelas, kelas X, XI, dan XII.

Sampel yang digunakan dalam penelitian ini yaitu 55 responden dari 122 siswa berasal dari kelas X, XI dan XII MA Miftahul Huda Cipayung Bogor. Adapun cara menentukan sampel pada penelitian ini, sampel dari populasi digunakan perhitunga maupun acuan tabel yang dikembangkan para ahli adapun rumus menentukan jumlah sampel menggunakan rumus slovin, yaitu:

$$
\mathbf{n}=\left(\frac{N}{N \times e^{2}}\right)
$$

Keterangan: $\mathrm{n}=$ sampel $=55 ; \mathrm{N}=$ populasi $=122 ; \mathrm{e}^{2}$ $=$ derajat kesalahan $(0,10)$

Dengan demikian margin error pada sampel penelitian ini sebesar 10\% dari 122 populasi menjadi 55 responden atau 55 sampel yang diambil.

\section{Teknik Pengumpulan Data}

Teknik pengumpulan data merupakan cara yang dilakukan peneliti untuk mendapatkan informasi yang dibutuhkan dari responden sesuai lingkup yang sedang diteliti. Dalam penelitian ini ada beberapa teknik pengumpulan data yang digunakan peneliti antara lain :

\section{Metode Tes Praktik}

Pada teknik pengumpulan data variabel kemampuan membaca Al-Quran peneliti menggunakan metode tes praktik untuk mengetahui kemampuan membaca $\mathrm{Al}$ Quran peserta didik. Peneliti melakukan penilaian langsung kepada peserta didik untuk mendapatkan data, dimana instrumen penilaian yang digunakan ditentukan sendiri oleh peneliti berpedoman pada aspek dan indikator kemampuan membaca Al-Quran.

\section{Dokumentasi}

Dokumentasi yaitu mengumpulkan data dengan melihat atau mencatat suatu laporan yang sudah tersedia.Metode ini dilakukan dengan melihat dokumen-dokumen resmi seperti catatan-catatan dan buku-buku peraturan yang ada. Dalam penelitian ini metode dokumentasi digunakan untuk memperoleh data mengenai jumlah siswa di MA Miftahul Huda, jumlah guru di MA Miftahul Huda, dokumen pembelajaran: silabus, RRP dan hasil evaluasi.

\section{Wawancara}

Wawancara merupakan suatu instrumen yang digunakan peneliti untuk mendapatkan data dan informasi secara lisan. Wawancara hendaknya dilaksanakan secara mendalam guna mendapatkan infoemasi yang jelas dan valid (Sujarweni, 2014). Wawancara dalam penelitian ini yaitu peneliti melakukan wawancara kepada wakil kepala sekolah bidang kurikulum MA Miftahul Huda untuk mengetahui bagaimana kemampuan membaca Al-Quran dan hasil belajar AlQuran Hadits secara keseluruhan kepada Bapak Agus Ma'mun selaku guru mata pelajara Al-Quran Hadits. 


\section{Observasi}

Observasi adalah pengamatan serta pencatatan yang dilakukan peneliti secara sistematis terhadap gejala-gejala yang terlihat pada objek penelitian. Dalam penelitian ini peneliti melakukan penelitian langsung terhadap peserta didik MA Miftahul Huda.

\section{Instrumen Penelitian}

Instrument penelitian merupakan alat atau fasilitas yang dapat mempermudah pekerjaan peneliti dalam mengumpulkan data yang dibutuhkan dengan hasil yang lebih baik, yaitu data yang lengkap dan sistematis sehingga lebih mudah untuk diolah dan dianalisis. Instrument penelitian yang digunakan dalam penelitian ini yaitu menggunakan uji praktik, responden diminta untuk membaca pada surah dan ayat yang sudah disediakan.

\section{Teknik Analisis Data}

\section{Uji Prasyarat Analisis Data}

Uji persyarat analisis diperlukan agar mengetahui bagaimana analisis pengelolaan data untuk pengujian hipotesis bisa dilanjutkan atau tidak (Supardi, 2012). Uji prasyarat yang pertama ialah Uji Normalitas (Llliefors). Uji normalitas diperlukan agar mengetahui normal atau tidaknya sebuah distribusi data, ini penting dilakukan mengingat berkaitan dengan keefesienan pemilihan uji statistik. Penggunaan Uji normalitas dalam penelitian ini yaitu Uji Lilliefors. Uji normalitas menggunakan Uji Lilliefors dilakukan jika data yang di peroleh ialah merupakan data tunggal atau data frekuensi tunggal, bukan, data berdistribusikan frekuensi kelompok. (Supardi, 2012). Yang kedua menggunakan Uji Linieritas yang diperlukan agar mengetahui bagaimana variable bebas $\mathrm{X}$ dan variable terikat $\mathrm{Y}$ berbentuk linier atau tidak, yang pertama kriteria uji linieritas regresi adalah jika $\mathrm{F}$ kurang dari 0,05 jadi hubungannya tidak linier sedangkan bila nilai sig lebih dari 0,05 atau sama dengan 0,05 maka hubungan bersifat linier. Kedua uji linier diperlukan melihat nilai $F_{\text {hitung }}$ dan $F_{\text {tabel, }}$ bila data $F_{\text {hitung }}$ lebih kecil dari data

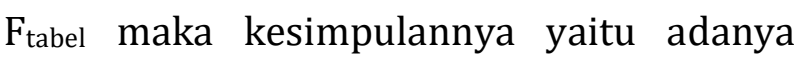
hubungan linier secara signifikan antara variable $\mathrm{X}$ dan variable $\mathrm{Y}$, begitu juga apabila jika nilai data Fhitung lebih besar dari nilai data $F_{\text {tabel }}$ kesimpulannya adalah tidak adanya hubungan linier diantara variable $\mathrm{X}$ dan variable Y. (Supardi, 2012).

\section{Analisis Deskriptif}

Analisis deskripstif bertujuan untuk menghasilkan gambaran terhadap focus yang akan diteliti melalui data sampel dan data populasi melakukan tanpa analisis dan mendapatkan kesimpulan yang telah berlaku secara untuk umum. Analisis statistika deskriptif meliputi modus, mean, standar deviasi, nilai maksimal \& nilai minimal (Sugiono, 2003).

\section{Korelasi Product Moment}

Korelasi product moment diperlukan agar bisa mengatahui ada tidaknya hubungan diantara variable $\mathrm{X}$ dan variable $\mathrm{Y}$. Sebagaimana dasar pengambilan keputusan apabila data nilai signifikansi $<0.05$ begitu juga sebaliknya apabila data nilai signifikansi > 0.05 maka tidak adanya terdapat korelasi. Berikutnya dengan tanda bintang $\left(^{*}\right)$ yang diperoleh dari SPSS, jika terdapat tanda $(*)$ maka antar variabel yang dianalisis terjadi korelasi, maka adanya terdapat korelasi (hubungan) sebaliknya sebaliknya bia tidak adanya tanda (*) maka tidak adanya terdapat korelasi. 


\section{Analisis Inferensial}

Teknik analisis untuk data yang akan dilakukan dalam penelitian ini ialah statistic inferensial. Sugiyono menuturkan bahwa statistik inferensial digunakan agar menganalisis jumlah data sampel dan hasilnya digunakan untuk populasi (Sugiono, 2003). Adapun rumus menggunakan regresi sederhana sebagai berikut :

$$
\begin{aligned}
& \hat{Y}=a+b X \\
& b=\frac{n \sum X Y-\sum X \sum Y}{n \sum X^{2}-\left(\sum X\right)^{2}} \\
& a=\bar{Y}-b \bar{X}
\end{aligned}
$$

Keterangan: $(\mathrm{Y})$ = variabel dependen; $(\mathrm{X})=$ variabel independen; $\mathrm{a}=$ konstanta (nilai $\mathrm{Y}$ untuk $\mathrm{X}=0$ ); $\mathrm{b}=$ angka arah/koefisian regresi. Yang menggambarkan jumlah peningkatan maupun penurunan variabel dependen yang diperoleh berdasarkan pada perubahan variabel independen. Bila $\mathrm{b}(+)$ maka arah regresi naik, dan arah regresi turun apabila b (-).

\section{Uji F}

Untuk menguji signifikansi koefiensi regresi dengan $\mathrm{F}$ regresi diperoleh menggunakan rumus :

$$
\mathrm{F}_{\mathrm{h}}=\frac{\mathrm{RJK}_{\mathrm{reg}(\mathrm{h} / \mathrm{a})}}{\mathrm{RJK} \mathrm{K}_{\mathrm{res}}}
$$

Keterangan: $\mathrm{F}_{\mathrm{h}}=\mathrm{F}$ hitung; $\mathrm{RJK} \mathrm{K}_{\mathrm{reg}(\mathrm{h} / \mathrm{a})}$ = rata-rata jumlah kuadrat regresi $\mathrm{h} / \mathrm{a} ; \mathrm{RJK}_{\text {res }}=$ rata-rata kuadrat garis residu.

\section{HASIL DAN PEMBAHASAN}

\section{Hasil}

Berdasarkan analisis keseluruhan data yang ada pada deskriptif data sudah dapat diketahui data hasil dari kemampuan membaca Al-Quran peserta didik MA Miftahul Huda 2016/2017 dan hasil belajar murid pada mata pelajaran Al-Quran Hadits yaitu data terdapat hasil skor tertinggi 12 , skor terendah 4, rata-rata8.04, standar devisi 2.553. Dapat dilihat pada tabel 1.

Tabel 1 Deskriptive variabel X

Descriptive Statistics

\begin{tabular}{lllllr}
\hline \multicolumn{4}{c}{ N Minimum Maximum Mean } & $\begin{array}{c}\text { Std. } \\
\text { Deviation }\end{array}$ \\
\hline $\begin{array}{l}\text { Kemampuan } \\
\text { Membaca }\end{array}$ & & 4 & 12 & 8.04 & 2.553 \\
Alquran & & & & & \\
Valid N & 55 & & & & \\
(listwise) & & & & & \\
\hline
\end{tabular}

Data hasil belajar murid pada mata pelajaran Al-Quran Hadits diperoleh skor terendah 65, skor tertinggi 88 rata-rata sebesar 77.27, standar deviasi 7.583. Sesuai dengan Tabel 2

Tabel 2 Deskriptive variabel Y

Descriptive Statistics

Std.

N Minimum Maximum Mean Deviation

\begin{tabular}{lrlll}
\hline $\mathrm{Y} \quad 55$ & 65 & 8877.27 & 7.583 \\
Valid $\mathrm{N}$ & & & \\
(listwise) & 55 & & & \\
\hline
\end{tabular}

Adapun persentase antar kemampuan membaca Al-Quran siswa dan hasil belajar siswa pada mata pelajara Al-Quran Hadits berada pada kategori sangat baik yaitu 43,7\% untuk hasil kemampuan membaca Al-Quran dan 34.5\% pada ketegori baik untuk hasil belajar murid pada mata pelajaran Al-Quran hadits.

Pada pengujian prasyarat analisis jumlah data pertama dilakukan uji normalitas, dengan jenis pengujian uji lilliefors dengan hasil data berdistribusikan normal yaitu nilai ASymp.Sig 0,182 0,05 \& 0,052<0,05 maka terdapat hubungan yang signifikan sesuai dengan tabel 3. 
Tabel 3 Uji normalitas lilliefors

\begin{tabular}{lrrrlll}
\hline \multicolumn{3}{c}{$\begin{array}{c}\text { Kolmogorov- } \\
\text { Smirnova }\end{array}$} & \multicolumn{3}{c}{ Shapiro-Wilk } \\
\hline \multicolumn{2}{c}{ Statistic } & df & Sig. & Statistic & Df & Sig. \\
\hline X & .106 & 55 & .182 & .938 & 55 & .007 \\
Y & .119 & 55 & .052 & .925 & 55 & .002 \\
\hline
\end{tabular}

a. Lilliefors Significance Correction

Tabel 4 Uji linieritas

ANOVA Table
Kedua pengujian prasyarat analisis data menggunakan uji linieritas dengan hasil Sig. $0,178>0,05$, jadi antar variable $\mathrm{X}$ (kemampuan membaca Al-Quran) dan variable Y hasil belajar Al-Quran hadit's ada hubungan bersifat linier sesuai dengan tabel 4.

\begin{tabular}{llcccccr}
\hline & & \multicolumn{2}{c}{$\begin{array}{c}\text { Sum of } \\
\text { Squares }\end{array}$} & df & Mean Square & F & Sig. \\
\hline Y & Between & (Combined) & 2086.623 & 8 & 260.828 & 11.783 & .000 \\
X Groups & Linearity & 1848.021 & 1 & 1848.021 & 83.482 & .000 \\
& Deviation & from & & & & & \\
& Linearity & 238.603 & 7 & 34.086 & 1.540 & .178 \\
\multicolumn{2}{l}{ Within Groups } & 1018.286 & 46 & 22.137 & & \\
\multicolumn{2}{l}{ Total } & 3104.909 & 54 & & & \\
\hline
\end{tabular}

Penelitian selanjutnya yaitu pengujian hipotesis dengan menganalisis data, yang pertama dengan menggunakan product moment untuk mengetahui ada tidaknya hubungan antar variable $\mathrm{X}$ (kemampuan Membaca Alquran) terhadap variable $Y$ hasil belajar Al-Quran Hadits dengan hasil nilai yang signifikansi $0,000<0,05$ berartikannya terdapat korelasi (hubungan) antara variable $\mathrm{X}$ dan variable $\mathrm{Y}$. Berdasarkan tanda $\left(^{*}\right)$ yang dididapatkan oleh program SPSS pada nilai $0,771^{* *}$ jadi, ada korelasi (hubungan) antar variable $\mathrm{X}$ dengan hasil belajar murid pada mata pelajaran Al-Quran hadit's. Dapat dilihat pada tabel 5.
Tabel 5 Korelasi product moment

Correlations

\begin{tabular}{lll}
\hline & \multicolumn{1}{c}{ X } & \multicolumn{1}{c}{ Y } \\
\hline X Pearson Correlation & 1 & $.771^{* *}$ \\
Sig. (2-tailed) & & .000 \\
N & 55 & 55 \\
Y Pearson Correlation & $.771^{* *}$ & 1 \\
Sig. (2-tailed) & .000 & \\
N & 55 & 55 \\
\hline$* *$
\end{tabular}

Selanjutnya pengujian hipotesis yang diperlukan ialah rumus regresi linier yang pertama persamaan regresi dengan hasil $\mathrm{Y=}$ $58.857+2.292 \mathrm{X}$ sesuai dengan tabel 6 . 
Tabel 6 Persamaan regresi

\begin{tabular}{|c|c|c|c|c|c|}
\hline \multirow{2}{*}{ Model } & \multicolumn{3}{|c|}{ Unstandardized Standardized } & \multirow{2}{*}{$\mathrm{t}$} & \multirow{2}{*}{ Sig. } \\
\hline & B & $\begin{array}{l}\text { Std. } \\
\text { Error }\end{array}$ & Beta & & \\
\hline 1 (Constant) & 58.857 & 2.187 & & 26.912 & .000 \\
\hline$X$ & 2.292 & .260 & .771 & 8.828 & .000 \\
\hline
\end{tabular}

Nilai koefisien (b) bertanda positif (2.292) dapat dikatakan hubungan antar kemampuan membaca Alquran dengan hasil belajar murid di mata pelajaran Al-Quran hadit's merupakan hubungan yang berbanding lurus. Artinya, meningkat tinggi kemahiran membaca Al-Quran murid, maka tinggi juga hasil belajar Al-Quran hadits yang diperoleh peserta didik sesuai dengan tabel 7.

Tabel 7 Signifikasi persamaan regresi

ANOVA $^{\mathrm{b}}$

\begin{tabular}{lllllll}
\hline \multicolumn{1}{c}{ Model } & \multicolumn{2}{c}{ Sum of Squares } & df & Mean Square & F & Sig. \\
\hline 1 & Regression & 1848.021 & 1 & 1848.021 & 77.927 & $.000^{\text {a }}$ \\
Residual & 1256.888 & 53 & 23.715 & & \\
Total & 3104.909 & 54 & & & \\
\hline
\end{tabular}

a. Predictors: (Constant), $\mathrm{X}$

b. Dependent Variable: Y

Pengujian hipotesi dengan menentukan signifikansi persamaan regresi dengan hasil nilai $F_{\text {hitung }} 77.927 \mathrm{dan} \mathrm{F}_{\text {tabel }}$ dengan $\mathrm{df}_{\mathrm{reg}}=1$ $\mathrm{df}_{\text {res }}=1$ adalah 4,03 pada taraf $5 \%$. Dengan demikian Fhitung $>$ Ftabel $(77.927>4,03)$ sehingga $\mathrm{H}_{0}$ ditolak, artinya ada pengaruh yang begitu signifikan antar kemampuan membaca Al-Quran dengan hasil belajar murid mata pelajaran Al-Quran Hadits.

Pengujian hipotesis yang terakhir yaitu menentukan koefisien determinasi diperoleh korelasi (hubungan) antar kemampuan membaca Alquran dengan hasil belajar murid mata pelajaran Alquran Hadits adalah 0,771 sesuai dengan tabel 8.

Tabel 8 memperlihatkan bahwa memiliki hubungan yang positif dan signifikan sebesar 0,771 antara kemampuan membaca Alquran terhadap hasil belajar. Koefisien determinasi yaitu $0,771^{2}=0.595$ dengan pernyataan diatas hasil belajar Al-Quran hadit's sebesar 59,5\% dipengaruhi oleh kemampuan membaca Al-Quran, sedangkan
40.5\% hasil belajar murid di mata pelajaraan Al-Quran Hadits terkombinasikan oleh faktor lain seperti faktor internal serta faktor eksternal.

Tabel 8 Koefisien determinasi

Model Summary

Std. Error of

R Adjusted R the

Model R Square Square Estimate

\begin{tabular}{lllll}
\hline 1 & $.771^{\mathrm{a}}$ & .595 & .588 & 4.86979
\end{tabular}

a. Predictors: (Constant), X

\section{Pembahasan}

Berdasarkan analisis data pada deskriptif data sudah dapat diketahui bahwa data kemampuan membaca Al-Quran peserta didik MA Miftahul Huda Cipayung Bogor 2016/2017 dan hasil belajar Al-Quran Hadits yaitu data terdapat hasil skor tertinggi 12 , skor terendah 4 , rata-rata 8.04 , 
standar devisi 2.553. Data hasil belajar AlQuran Hadits diperoleh skor terendah 65, skor tertinggi 88 rata-rata sebesar 77.27, standar deviasi 7.583. Adapun persentase antara kemampuan membaca Al-Quran dan hasil belajar Al-Quran Hadits berada pada kategori sangat baik yaitu 43,7\% untuk kemampuan membaca Al-Quran dan 34.5\% pada ketegori baik untuk hasil belajar AlQuran hadits.

Pada pengujian prasyarat analisis data yang pertama dilakukan uji normalitas, dengan jenis pengujian uji lilliefors dengan hasil data berdistribusi normal yaitu nilai ASymp.Sig 0,182 < 0,05 dan 0,052<0,05 maka terdapat hubugan yang signifikan. Kedua pengujian prasyarat analisis data menggunakan uji linieritas dengan hasil Sig. $0,178>0,05$, maka antara variabel $\mathrm{X}$ kemampuan membaca Al-Quran dan hasil belajar Al-Quran hadits terdapat hubungan yang bersifat linier. Penelitian selanjutnya yaitu pengujian hipotesis dengan menganalisis data, yang pertama dengan menggunakan product moment untuk mengetahui ada tidaknya hubungan antara variabel X kemampuan membaca Al-Quran terhadap variabel Y hasil belajar Al-Quran Hadits dengan hasil nilai signifikansi 0,000 $<0,05$ yang artinya terdapat korelasi antara variabel X dan Y. Berdasarkan tanda (*) yang diberikan oleh program SPSS pada nilai $0,771^{* *}$ maka terdapat korelasi antara variabel X kemampuan membaca Al-Quran dengan hasil belajar Al-Quran Hadits peserta didik.

Selanjutnya, pengujian hipotesis dengan menggunakan rumus regresi linier yang pertama persamaan regresi dengan hasil $\mathbf{Y =}$ 58.857+2.292 X, Karena nilai koefisien (b) bertanda positif (2.292) dapat dikatakan hubungan antara kemampuan membaca $\mathrm{Al}$ Quran dengan hasil belajar Al-Quran Hadits merupakan hubungan yang berbanding lurus. Artinya semakin tinggi hasil belajar, semakin tinggi pula hasil belajar Al-Quran Hadits peserta didik.

Pengujian hipotesis dengan menentukan signifikansi persamaan regresi dengan hasil nilai F $F_{\text {hitung }}$ 77.927dan $F_{\text {tabel }}$ dengan $d_{\text {reg }}=1$ $\mathrm{df}_{\text {res }}=1$ adalah 4,03 pada taraf $5 \%$. Dengan demikian Fhitung $>$ Ftabel $(77.927>4,03)$ sehingga $\mathrm{H}_{0}$ ditolak, artinya terdapat pengaruh yang signifikan antara kemampuan membaca Al-Quran terhadap hasil belajar Al-Quran Hadits. Pengujian hipotesis yang terakhir yaitu menentukan koefisien determinasi diperoleh korelasi antara kemampuan membaca Al-Quran terhadap hasil belajar mata pelajaran AlQuran Hadits adalah 0,771 artinya terdapat hubungan yang positif dan signifikan sebesar 0,771 antara kemampuan membaca Al-Quran terhadap hasil belajar. Koefisien determinasi yaitu $0,771^{2}=0.595$ dengan demikian hasil belajar Al-Quran hadits sebesar 59,5\% dipengaruhi oleh kemampuan membaca Al-Quran, sedangkan $40.5 \%$ hasil belajar Al-Quran Hadits dipengaruhi oleh faktor lain yaitu faktor internal dan faktor eksternal.

\section{KESIMPULAN DAN IMPLIKASI}

\section{Kesimpulan}

Persamaan regresi pada penelitian dengan indeks korelasi 0,771 dan nilai signifikan sebesar 0.000 dan nilai $F_{\text {tabel }} 0.05$, maka antara nilai signifikansi $0,000<0,05$ yang artinya terdapat korelasi (hubungan) antar variabel $\mathrm{X}$ dan $\mathrm{Y}$. Berdasarkan pengujian korelasi dengan product moment terdapat korelasi antar hasil belajar murid mata pelajaran Al-Quran Hadits dengan kemahiran dalam membaca Al-Quran peserta didik. Pada persamaan regresi $\mathrm{Y}=$ $58.857+2.292 \mathrm{X}$ dikatakan hubungan antar 
kemampuan membaca Al-Quran dengan hasil belajar murid mata pelajaran Al-Quran hadits merupakan hubungan yang berbanding lurus. Artinya semakin tinggi hasil kemampuan membaca Al-Quran, semakin tinggi juga hasil belajar. Adanya pengaruh signifikan antar kemampuan membaca Al-Quran dengan hasil belajar murid di mata pelajaran Al-Quran hadits dengan $F_{\text {hitung }} 77.927$ dan $F_{\text {tabel }}$ dengan $\mathrm{df}_{\text {reg }}=1 \mathrm{df}_{\text {res }}=54$ adalah 4,03 pada taraf $5 \%$. Dengan demikian $F_{\text {hitung }}>F_{\text {tabel }} 77.927>$ 4,03 sehingga $\mathrm{H}_{0}$ ditolak, Besar koefisien determinasi atau $\mathrm{R}$ Square 0,771 artinya hasil murid belajar Al-Quran hadits sebesar 59,5\% dipengaruhi oleh kemampuan membaca Al-Quran, sedangkan 40.5\% hasil siswa belajar Al-Quran hadits terkombinasikan oleh faktor-faktor lain yaitu faktor dari dalam dan luar diri peseta didik.

\section{Implikasi}

Penelitian ini memiliki dampak yang sangat signifikan, baik bagi peserta didik, lembaga pendidikan, serta pendidik, karena mata pelajaran Al-Quran Hadits harus mampu memberikan pelajaran yang bisa meningkatkan hasil kemampuan membaca Al-Quran peserta didik. Dalam evaluasi pembelajaran mata pelajaran Al-Quran Hadits perlu diperhatikan kembali apa yang menyebabkan nilai peserta didik pada mata pelajaran Al-Quran Hadits belum mencapai prestasi yang tinggi atau hanya, misalnya perlu ada perhatian khusus pada peserta didik yang nilai hasil belajarnya rendah.

\section{DAFTAR PUSTAKA}

Arifin, Z. (2012). Penelitian Pendidikan Metode dan Paradigm Baru. Bandung: Remaja Rosda Karya.

Departemen agama RI. (1971). Al-Quran dan Terjemahan.

Departemen pendidikan nasional. (2008). KBBI. Jakarta: Gramedia Pustaka.

Susanto, A. (2013). Teori Belajar dan Pembelajaran di Sekolah. Jakarta: Fajar Imerpratama group.

Supardi. (2012). Aplikasi Statistika dalam Penelitian. Jakarta: Ufuk press.

Sujarweni, W. (2014). Metodologi Penelitian. Yogyakarta: Pustaka Baru Press.

Sugiono. (2003). Metode Penelitian Administrasi. Bandung: Alfabeta.

Tafsir, A. (2004). Ilmu Pendidikan dalam Perspektif Islam. Bandung: Remaja Rosda Karya. 